\title{
Another Nakba: Weapons Availability and the Transformation of the Palestinian National Struggle, 1987-2007
}

\author{
Francesco Strazzari \\ Scuola Superiore Sant'Anna \\ Simone Tholens \\ European University Institute
}

\begin{abstract}
Violent clashes of June 2007 saw Hamas ousting Fatah from the Gaza Strip, thereby making patent the existence of a deep politico-military split within the Palestinian national movement. This article sheds light on the present face of the conflict in the Palestinian territories by adopting a historical-analytical perspective that emphasizes the role played by the availability of small arms and light weapons, as one of the many structural factors that underlie the transformation of the Palestinian struggle. Aware of the essentially contestable and reductionist nature of this endeavor, the authors examine the way in which the weapons acquisition process has changed in the time period from the beginning of the first Intifada in 1987 to the Gaza take-over by Hamas, 20 years later. In doing this, they extend the applicability of existing theories about the correspondence between access to weapons and the changing nature of insurgency, so to better understand a complex case where a national struggle has been spiralling into internecine violence and splintering, in what we may call "another Palestinian Nakba."
\end{abstract}

Keywords: small arms, armed groups, Palestinian/Israeli conflict

Armed struggle played a critical role in the history of Palestinian emancipation from the patronage of Arab governments, and the lesson learnt from the disastrous outcome of the 6-day War in 1967 was that victory had to be achieved by the Palestinians themselves. As Fatah took control of the Palestinian Liberation Organization (PLO) in 1969, and Yasser Arafat became the new leader of an indigenous movement for a Palestinian homeland, armed struggle generated a sense of coherence and purpose that had until then been weak among the Palestinians (Sayigh 1997). The internecine fighting that broke out as Hamas took control of the Gaza Strip in June 2007 thus raises a set of crucial questions: how did the Palestinian movement change, within a relatively short time span, from being a largely coherent insurgent liberation movement that negotiated an internationally monitored peace agreement with Israel in 1993 into a catastrophically divided movement in terms of both territory and direction of the resistance? How did a society that mobilized in the face of a powerful threat to national survival end up splintering and find itself on the verge of triggering a civil war?

It is beyond doubt that this is a complex issue, and that it would be necessary to undertake a comparative research of all the relevant dynamics affecting the 
Palestinian society if we are to gain complete understanding of these developments. Yet, even before conceiving of such a research effort, the researcher is confronted with a striking paradox. In a nation- and state-building perspective, the question of "who controls weapons" leads to the very heart of the Weberian "monopoly of violence" that lies at the core of statehood. However, the topic is virtually absent from scholarly research on the Palestinian movement. Researchers have, perhaps, been discouraged from engaging in an analysis based on the factor of arms acquisition due to the difficulty in acquiring direct and reliable sources and data, as well as the abundance of manipulated accounts of events. The resulting situation is one in which such a central factor as weapons availability is in fact made the object of little academic research.

On the backdrop of the current situation, in which Fatah's ambiguous attitudes to Israel's 2009 war in Gaza and subsequent deepening of intra-Palestinian divisions puzzles the world, we ought in this article to shed light on the pervasive role that weapons availability has played in shaping the course of the Palestinian armed struggle. The ultimate point of analysis is centered on deepening our understanding of the profound division and intense fighting that exploded in the streets of Gaza in June 2007 between Hamas and its sympathizers on the one hand and the Palestinian Authority (PA) represented by Fatah on the other. This is particularly relevant as the Gaza war of 2009 revealed how crucial simple weapons, as for example, homemade rockets are, for directing the theater of war in a situation of asymmetric warfare. The extent to which Israel has militarily and diplomatically targeted the smuggling tunnels under the Rafah border crossing between Gaza and Egypt further reveals how crucial simple and small weapons have come to be in this conflict. Discoveries of Israeli air strikes in Sudan aimed at alleged arms shipments from Iran during the course of the Gaza war further point to the length at which Israel is willing to go in order to prevent weapons from entering Palestine. In other words, even in such situations of extreme asymmetry the arms factor may impact the direction, intensity, and mode of conflict. Further, as Benoit Challand points out in a recent commentary, the arming of multiple actors within the movement(s) has proven to reflect different views on the modus operandi of security provision within the Palestinian territories; while Fatah prefers the Oslo model, which engages a multitude of fragmented police structures that are also linked to economically important import monopolies, Hamas has introduced an alternative organization, based on the "people in arms" model in which local security providers are armed in a bottom-up manner (Challand 2009). This, in turn, poses yet another hurdle to overcome in the process towards Palestinian unity. In this article we do not argue that weapon dynamics can provide an all-encompassing explanation of this conflict, but by engaging in a reductionist analysis of the Palestinian struggle this article wishes to highlight a factor that previously has been neglected in relevant academic research.

In setting out on this exploration, some theoretically driven expectations concerning arms availability and contemporary conflicts can be derived from recent empirically grounded research conducted chiefly by Bourne (2007) and Marsh (2007). These contributions fall within the debate on how technology alters the character of war, a debate that is concerned with how material factors interact with social and political, strategic and tactical developments. By building on these contributions, we scrutinize the role that small arms and light weapons have played over the historical course of the Palestinian mobilization, so as to provide a viewpoint that may shed light on the specific trajectory of the Palestinian-Israeli conflict. In addition, and aiming at a wider application, ${ }^{1}$ this analysis seeks to

\footnotetext{
${ }^{1}$ This study can be defined as a "disciplined interpretive case study" (Odell 2001) — that is, one that may not necessarily test a theory, but which shows how theoretically driven expectations may be extended to account for a new event.
} 
contribute to the growing field of studies concerned with small arms and light weapons in contemporary conflicts, and in particular to the growing sub-field concerned with the demand for weapons within armed groups.

\section{Armed Groups and Arms Availability}

The reason armed non-state groups have received growing attention in contemporary conflict studies has little to do with the presumed novelty of these actors. Rather, it is due to a growing body of literature observing how warfare is changing. According to this literature, wars can no longer be explained through predominantly Clausewitzian lenses, in which a linear logic explains how war is the continuation of politics by other means, and how the battle is the focal point of war. This argument has become paramount not only in the literature on "new wars" (Kaldor 1999), and on "post-modern warfare" (Duffield 1998), but also in classic critiques of Clausewitz's triadic conception of war (for example, Van Creveld 1997). In this literature armed groups can be seen as tiles of post-Cold War complex conflict mosaics, where shadow war economies explains various levels of both collusion and collision, and the relevance of the state must be demonstrated rather than assumed (Kaldor 2005). ${ }^{2}$ For the researcher who seeks to move the study of war and international relations beyond the horizon where the state is held to be the ultimate cornerstone of theorizing, the first definition from which the exploration can start is that "armed groups" are characterized by the fact that they are "armed" (Marsh 2007:55). There exists surprisingly scant literature on the relationship between weapons and armed groups. A large part of the studies that exist are concerned with supply-side issues, such as regional conflictcomplexes (for example, Bourne 2007), or studies of conflict outcomes (for example, Sislin and Pearson 2001). A few outstanding qualitative studies of particular cases have attempted to trace the flow of weapons in conflict-complexes in order to understand the role of illicit arms in conflicts (for example, Klare and Andersen 1996; Eavis 2002; Duquet 2008). Far less has been written on demand dynamics within armed groups or within areas witnessing armed conflict involving nonstate belligerents, though there have been explorations on this from an anthropological perspective. This may well pertain to the fact that disarmament circles are mostly concerned with the supply side: disarmament experts and diplomats have been largely oriented by states and state interests, focusing primarily on marking and tracing, on export and import control, on containing the role of arms brokers, and on the destruction of surplus weapons. This is in part due to the limited scope that an international treaty or agreement can address, but the failed agreement on regulations on export to nonstate actors in the $2001 \mathrm{UN}$ Programme of Action to Prevent, Combat and Eradicate the Illicit Trade in Small Arms and Light Weapons in All Its Aspects, the most comprehensive universal political framework existing, may reveal a reluctance of states to recognize the intricate role of demand in contemporary conflicts. Such an emphasis on the supply side has been revealed as a bias in, for example, Atwood, Glatz, and Muggah (2006), who highlight the need for addressing demand dynamics within armed groups in order for disarmament initiatives to be successful.

The reason the following analysis focuses on small arms and light weapons is that they are the preferred weapons in contemporary warfare (Sislin and Pearson 2001); as shall be demonstrated, the Palestinian case is no exception.

\footnotetext{
${ }^{2}$ Starting from these premises, little justification can be found for excluding "secondary" or "marginal" actors such as "criminal organizations" and "private security providers" from the analysis of how conflict patterns evolve. Accordingly, dynamics linked to the presence of these actors are not excluded from the following analysis of the Palestinian "weapons demand complex."
} 
Such weapons must be dealt with differently, both from an analytical and a strategic viewpoint, than major weapon systems due to the ease with which they are deployed, their mobile nature, and the ambiguous position they often hold between the licit and the illicit. The wars, genocides, and atrocities of the 1990s illustrated the brutality and lethality that can be inflicted by such weapons, and there are emerging norms concerned with the control of Small Arms and Light Weapons (SALW) (cf. Garcia 2006). In the case of Palestine the significance of weapons falling under this category is illuminating; even where an insurgency is being confronted by one of the world's most advanced military apparatuses light weapons are ubiquitous.

Nicholas Marsh (2007) points to the existence of a correspondence between arms availability, the modes in which armed groups acquire arms, and the type of insurgency. Perceptions of availability are highly subjective, ranging along a continuum from scarcity, the most common perception among insurgents, to abundance, typically the most common perception among concerned external observers (Marsh 2007:61). Instead of relying exclusively on the alleged amount of weapons, therefore, it is more fruitful to develop an understanding of "who has them, and how difficult it is for armed groups to obtain them" (ibid.). Moreover, Marsh finds it useful to incorporate the control factor into the explanatory framework - that is, whether the leadership of an armed group monopolizes the acquisition, or, on the contrary, if weapons are easily accessible to every insurgent in the field.

Bourne draws a distinction between acquisition by the group's leadership and by the combatants themselves, in what can be understood as either a "top-down" or a "bottom-up" mode of arming (Bourne 2007:181-205). Along this line one can look at arms as the propellant that shapes organized violence: those actors who control the process of weapons acquisition gain influence also in controlling the tactical direction and the strategic objectives of the insurgency. According to Marsh, therefore, there is a close link between the characteristics of actors with access to weapons within an armed group, or within an "armed movement," and the "mode of insurgency." In cases of low availability one is likely to find that the armed group's leadership is in charge of procuring the weapons and distributing them to its cadres. The insurgency is thereby likely to be characterized by one single, highly united and organized armed group, as access to weapons by the insurgents in the field is strictly bound to the ideological and strategic goals laid out by the leadership. In a situation of medium availability of weapons the insurgency is more likely to take the form of a warlord-structured organization (Marsh 2007:70), as regional commanders have access to weapons and are crucial in distributing the weapons. In this scenario the regional commanders become semi-autonomous and operate as leaders of smaller factions, whilst still operating ultimately at the behest of the political leadership of the movement, which steers the insurgency from a macro level. The third type of insurgency is characterized by societies saturated with weapons and, accordingly, in a situation of armed conflict individual combatants have high access to arms (Marsh 2007:75). In such a scenario there exists no monopoly on the acquisition process by any particular group or segment, and the insurgency is defined by a plentitude of groups, as well as individuals or families, that are engaged in a war without clear nodes of orientation. In a context of high arms availability there is little incentive to operate under a rigid leadership, and anyone who wishes to engage in armed struggle has the opportunity to take up arms.

These three categories are useful in attempting to identify trends in contemporary conflict patterns, and highlights that weapons availability is a factor that underlies how insurgencies are amendable also according to structural/material changes. By subscribing to Marsh's broad conceptualization of availability we aim to provide a desk-based assessment of the dynamics between Palestinian armed 
groups engaging in violent conflict, and the means with which this conflict is fought.

In isolating arms availability as the key factor over time- and space-specific circumstances, we seek to explore changes in armed groups' internal organization patterns, so as to draw attention to how intra-state conflicts are affected by weapon dynamics: shifting conflict trends can thus be partially traced to the level of (small) arms availability. By looking at such an atypical and complex case as the Palestinian movement, we wish to consolidate the validity of this argument.

\section{The Palestinian Movement: Arms and Leadership}

The Palestinians' struggle for self-determination and national survival has a long and complex history that can in no way be simplistically read as just a function of weapons availability and control. Nonetheless, this article contends that key aspects characterizing the trajectory of the Palestinian struggle since the first Intifada erupted in 1987 and via the second al-Aqsa Intifada of 2000 can be illuminated through an exploration of patterns referring to weapons availability in the West Bank and Gaza Strip.

A number of factors and political developments can be put forth as explaining how the minimal sovereignty enjoyed by the PA has been challenged in a number of ways over the period we examine. First, the financial help from Arab countries to the PLO leadership was more than halved as a result of Arafat's choice to support Saddam Hussein in the Gulf War of 1991 (Sayigh 1997:657). Second, friction developed as a result of the return en masse of PLO affiliates, who received key positions and jobs, to the detriment of the young generation of militants who protagonized the first Intifada (Challand 2007). Third, Islamist movements that rejected the settlement with Israel embodied in the Oslo Agreement were on the rise. Further, the Palestinian people have found themselves at the mercy of an array of different states, with different interests in molding and utilizing their cause. Finally, behind the negotiation table Israel was perpetuating its own occupation policies, de facto outsourcing major security concerns to autochthonous elites so as to minimize the costs, without ever getting to a breakthrough in the final rounds of the negotiation. Moreover, Israel's occupation has had a distinct character, since it has drastically altered the territory, making mobility and communication extremely precarious, when not impossible. The combination of these factors has posed challenges to the unity of the struggle for a Palestinian national identity and the coherence in organizing the quest for a homeland.

To examine the role of the factor "access to arms" in this complex context is not straightforward. However, it is a blank in existing research on the potential existence of a correspondence between what is known of the history of weapons availability in this region and key developments in the political story of the Palestinian mobilization in the West Bank and Gaza. By spanning two decades, from the onset of the first Intifada in 1987 to the "Battle for Gaza" of 2007 in which Fatah was expelled from the Strip, this present exploration encompasses two critical developments in recent history: the inception of the Palestinian Authority in July 1994 and the flaring up of the second Intifada in 2000.

Although pacifist options have not been entirely absent in Palestinian history, centuries of occupation and several violent revolts constitute the mold and provide the repertoire in which the Palestinian identity and its modes of activation are shaped. The early twentieth century saw the Arab Revolt (1916-1918) and the Arab Revolt in Palestine (1936-1939), with the latter representing the first mobilization of a national Palestinian identity. Morris (1999) has argued that the British success in confiscating the weapons possessed by the revolting Arabs, as well as the 
elimination of their leadership, hampered the Palestinian cause during the 1948 war, which is remembered as the first nakba (national catastrophe).

Founded in 1964 under the guidance of Egypt's president Nasser, the PLO, with the rise of the nationalist, secular and revolutionary Fatah, in 1969 became a hierarchically structured national liberation movement, active at the social as well as the military level through the Palestinian Liberation Army (PLA). Nonetheless, the PLO can be said to have been a relatively pluralistic organization, as various groups that were part of it undertook separate attacks and guerrilla operations during the 1970s and 1980s. The most prominent among these formations were the Marxist-Leninist groups Popular Front for the Liberation of Palestine (PFLP) and the Democratic Front for the Liberation of Palestine (DFLP). While there were a myriad of Palestinian groups and political parties that were not members of the PLO, ${ }^{3}$ the acknowledgment of a Palestinian identity through the recognition of the PLO fomented popular support among the Palestinian public for this, to some extent, central control.

Following 13 years of armed opposition against Israel, the Palestinian leadership of the PLO was eventually co-opted in Beirut in 1982 and forced into exile in Tunis, separated from its constituencies scattered over the Arab world. Up until this point the PLO had been "regularizing" its armed wings in an attempt to embody a statist doctrine, and was successfully engaged in an international arms supply network, largely facilitated by the Cold War order: the strength of the Palestinian armed forces and, importantly, their ability to train and equip Third-World countries and insurgencies was crucial in gaining diplomatic support for the struggle (Sayigh 1997:448-454). The ousting of the PLO from its stronghold in Lebanon was a major blow to both the statist organization and to the build-up of military strength. The weapons that remained in PLO hands as the Palestinians left Lebanese soil to head for sanctuaries in the Arab world were handed over to the Lebanese Army, while the Israeli Defence Forces (IDF) confiscated the remaining weapons (Sayigh 1997:538). Yet, the PLO maintained its position as leader of the Palestinian struggle, and its leadership and influence was not seriously challenged until the first Intifada. The issue of small arms and light weapons became significant when a change in the resources mobilized for Palestinian struggle for self-determination occurred: up until the first Intifada the PLO had conceptualized liberation exclusively in military terms, and therefore postponed an attack until armed forces were in place that could match the Israeli might (Legrain 1997:160). The Intifada conceptualized the fight for liberation differently, namely by engaging the entire society inside the West Bank and the Gaza Strip in a popular uprising. From this moment, we shall argue, the accessibility of weapons became a key determinant of the armed struggle for a Palestinian homeland.

\section{The First Intifada}

The outbreak of the first Intifada in 1987 was principally a spontaneous reaction by the Palestinians living in Gaza and the West Bank. In this phase of the occupation, access to weapons was minimal; Israeli forces were present inside the Palestinian cities, and their control of the Territories appeared to leave little room for the circulation of weapons. Some light weapons were, however, employed in the clashes with the Israeli army: reportedly, Molotov cocktails, hand grenades, as well as guns and explosives whose use was witnessed in a handful of incidents. The use of knives in lethal attacks defined the so-called "white weapon Intifada." In many respects, as Sislin and Pearson (2001) also

${ }^{3}$ For a genealogical diagram of Palestinian organizations see Yezid Sayigh (1997:xlii). 
proposed, the first Intifada is an exception-that is, a case whose testing does not confirm the thesis whereby the presence of arms is a necessary precondition to the onset of violent "ethnic conflict": Low access to arms did not prevent the Palestinians from rebelling against their occupiers.

The Intifada presented an unprecedented threat to the PLO leadership in exile. At the beginning of 1988 a group of young Palestinian activists appeared as the organizing command unit behind attacks on Israeli positions. The militant youth that formed this unit were born out of a different Palestinian reality than that of the old leadership that followed Arafat into exile; they were too young to have known anything but the Israeli occupation, and their acts spoke of the urge to conquer a freedom that they had never seen. Their command body, the Unified National Leadership of the Uprising (UNLU), used methods and ideas of anti-occupation that appealed to fellow Palestinians in the Territories: "a revolt of stones and Molotovs" was their motto (Legrain 1997). The position they conquered over the summer of 1988 was unique, "it challenged both Israel's control of the territories and the absolute authority of the PLO abroad, playing cat-and-mouse with the Israelis while deftly sidestepping the orders coming out of Tunis" (Schiff and Ya'ari 1989:189; See also Challand 2008).

Arafat proved adamant towards challenges to his leadership and would not under any circumstances allow the young leadership any function other than that of subordinates in the Territories, rejecting moves that would indicate that UNLU resembled a nascent "partner" of the PLO. However, from 1991 the PLO focused mainly on the diplomatic front, "out-sourcing" the mobilization to groups in the Territories, namely the Black Panthers of Fatah, the Fatah Hawks, and the Red Eagles of PFLP (Legrain 1997). The local leadership had made peace with the fact that it would not be allowed to assert its independence and that none of its members would ever be hailed as a hero of the Intifada (Schiff and Ya'ari 1989:91). The threat posed by the Unified National Leadership under the first Intifada was effectively contained by the PLO leadership: UNLU's members remained fairly anonymous and, eventually, submissive to Yasser Arafat's supreme rule. Clearly, a certain opposition was prominent in the early phase of UNLU's existence, but all evidence indicates that shortly thereafter this body operated under the control of the PLO.

Eventually the Unified National Leadership defined itself as "a large coalition of combat brought about by the Intifada, made up of the main PLO forces represented in the Occupied Territories, Fateh, the Palestine Communist party, the PFLP, the DFLP, and other patriotic forces, patriotic committees, institutions, patriotic personalities and patriotic religious forces committed to the program of the PLO" (Nasser and Heacock 1991:180). By contrast, another formation, which emerged in the context of the first Intifada-the newly founded Hamas (Harakat al-Muqawama al-Islamiyya) — diverted in several critical aspects from the PLO program, operating independently of the overarching structures of the Palestinian movement. The newly founded Islamist group sprang out of the Muslim Brotherhood, which had so far not been able to gain more than a rather weak position among the Palestinians. Hamas' coordination and cooperation with UNLU during the first phase of the Intifada was successful and fairly tension-free at a tactical level, despite its diverging attitude towards the Palestinian movement's forms of resistance. Hamas directly opposed the diplomatic efforts made by the PLO to create a peaceful two-state solution; the strategic pursuit by Hamas' leadership was "no to peace with the Zionist entity" (Nasser and Heacock 1991:183). Political differences between Hamas and UNLU gradually surfaced, and tension rose to critical levels over the course of the Intifada years. 
The PLO was concerned by the emergence of parallel, defiant structures within the national camp, and sought to contain the growth of Hamas first by diplomatic means (Tamini 2007:187-190). Hamas was, by this time, a predominantly political organization with a social agenda structured by clientelistic networks, and it was not in a position to challenge the Fatah-led process toward a peace agreement with Israel in an authoritative manner. The shortage of weapons available to the Hamas leadership is a significant factor when seeking to explain its lack of engagement with the intra-Palestinian hegemonic struggles: as Zaki Chenab parsimoniously explains, "they lacked unity, direction and a consistent military strategy, let alone weapons" (Chenab 2007:22). Israel's heavy military presence in Gaza, allowing strict control over the border with Egypt, quite effectively restricted the weapons available to armed groups in the Gaza Strip (Chenab 2007:51). And the Gaza Strip was and continued to be the home base for Hamas, from its inception in 1987 until today.

\section{The Short Summer of Oslo}

The 1993 Oslo Agreement is a watershed in the history of Palestine, and a turning point for reconstructing the story of weapons availability. The Interim Agreement (or Oslo II of 1995) stipulated that the newly established Palestinian Authority was to create a police and security force. On the Palestinian side, the future PLO-returnees ran the show, bypassing the leaders of the Territories as they met with Yitzhak Rabin's experts. As a result of the diplomatic process, almost 100,000 PLO affiliates returned, making up the lion's share of the ranks in the newly created security units and PA administrative positions. The PA was given different levels of control in areas A, B, and C. In the Gaza Strip (area A) the PA police and security forces were to be fully responsible for all security activities, although the IDF still maintained a presence. Gaza is therefore of particular relevance in respect to leadership and arms, since both factors were considerably altered with the inception of the PA.

Importantly, Oslo II was the first international agreement that permitted Palestinian ownership of weapons. Some observers criticized the limitations on the armament of the Palestinian police and security forces, arguing that the volatile situation on the ground meant that these forces were the only actors capable of adequately estimating the number of troops and weapons required to implement the rule of law (Kuzmar 2002). From the very inception of the PA and the establishment of a Palestinian police and security force under its control, a distinction between legal and illegal weapons emerged. Legal weapons were those assigned to the PA men in uniform as well as those licensed to screened individuals. ${ }^{4}$

The PA forces, under the control of the Ministry of Interior, were not allowed to exceed a total of 30,000, making use of no more than 15,000 small and light weapons. In other words, the authorized weaponry available to the PA forces was limited to one weapon for every two police officers. A plethora of additional requirements regulated the presence of weapons under the PA, including strict guidelines for regulating civilian arms possession, in which it was specified that

\footnotetext{
${ }^{4}$ See Interim Agreement, Annex I Article IV $\$ 5$ b: "In the West Bank, the Palestinian Police will possess the following arms and equipment: up to 4,000 rifles; up to 4,000 pistols; up to 120 machine guns of $0.3^{\prime \prime}$ or $0.5^{\prime \prime}$ caliber; and up to 15 light, unarmed riot vehicles of a type to be agreed on between the two sides in the JSC. c: In the Gaza Strip, the Palestinian Police will possess the following arms and equipment: 7,000 light personal weapons; up to 120 machine guns of 0.3 " or 0.5 " caliber; and up to 45 wheeled armored vehicles of a type to be agreed on between the two sides, and of which 22 will be deployed in protecting Council installations. The use of wheeled armored vehicles in the Security Perimeter, on the Lateral Roads and on their adjacent sides, or in the vicinity of the Settlements shall be approved through the relevant DCO. Movement of such vehicles along the central NorthSouth road (Road No. 4) in the Gaza Strip may take place only after providing notification to the relevant DCO."
} 
the Palestinian police must issue permits for individuals to legally possess and carry arms, and that any illegal weapons should be confiscated. Shortly after the establishment of the PA, the circulation of illegal weapons among Palestinians became an issue of concern: Israeli reports accused the PA leadership not only of failing to crack down on illegal weapons, but also of being directly involved in smuggling operations under the cover of the VIP status enjoyed by PA vehicles and aircrafts (Boutwell 2002:300).

The influx of arms into a fragile and tense region was one of the major stumbling blocks to further implementing the peace agreements. In 1998 Jeffrey Boutwell, one of the pioneer-researchers on small arms and one of the few that has paid heed to this issue in Palestinian society, reported that

\footnotetext{
According to reliable sources, there are some 10,000-15,000 illegal weapons in Palestinian hands, ranging from World War II-vintage Sten guns and Webley pistols to modern AK-47 Kalashnikov and M-16 assault rifles-and perhaps grenade launchers and anti-tank and anti-aircraft portable missiles. (Boutwell 1998:42)
}

A wide array of small arms and light weapons is therefore reported to have been present in the Palestinian societies in the West Bank and Gaza by the late 1990s. These weapons were both legal and illegal, but such a differentiation was increasingly ambiguous and it was evident that the PA was struggling to keep control of the arms present in its territory.

The PA may have illegally procured arms for two main reasons. Firstly, the limited weaponry provided for by Oslo II was perceived among the factors that made the task of providing security extremely problematic, thus fuelling the search for further procurement. Secondly, a growing opposition against the Oslo Agreement and therefore against the Oslo Agreement's agent, the PA, seriously undermined the popularity of Fatah. Arms acquisition can therefore be seen as an attempt to balance the relative power between the ruling party and opposition groups.

Concomitant to PA arms acquisitions, popular support for radical organizations, primarily Hamas and other Islamist groups such as the Palestinian Islamic Jihad grew, allowing these groups to create parallel security networks alongside the PA. While Islamic Jihad is today a rather marginal organization (albeit still with the capacity to strike militarily) the 1990 were momentous for this group, in particular as suicide bombings enabled small groups to take ownership over the direction of the larger movement. Comparable to Hamas in its ideational basis and violent means of achieving it, Islamic Jihad in Palestine was, and is, a purely military organization, without the social dimension that has characterized Hamas' way of organizing the struggle. In the first half of the 1990s it has been reasonably well documented that the Islamist groups received covert support from Israel, because the latter wished to encourage the rise of a religious alternative that would undermine the popularity of the Palestine Liberation Organization and Arafat (Sale 2002). It is, however, uncertain whether these groups were given access to substantial supplies of weapons; Chehab (2007:43) quotes an informant who explains that "when [Hamas] began their attacks in 1991, they had at their disposal no more than twenty machine guns which remained the sum total of their arsenal until the year 2000." Armed groups' activities in the Gaza Strip were highly restricted due to Israeli patrolling, in addition to severe crackdowns by the PA security forces. Reportedly, Palestinian collaborators in the Territories were the best sources for weapons at the time, since they were often well armed by their patrons. The first step in Hamas' arms procurement strategy was thus the targeting of these collaborators and their weapons arsenals (ibid.). Parallel to this, in the mid-1990s Hamas developed the ability to produce explosives, which were used for roadside bombs and 
suicide bombings, and which elevated the group's standing in the intraPalestinian theater. ${ }^{5}$ Their adoption of the use of explosives, a relatively easily acquired and cheap weapon, in advocating their cause can, in fact, be seen as a harbinger for the future pervasive role of Hamas in the Palestinian armed struggle.

As highlighted above, the consolidation of the armed challenge to the PA is in several ways also a function of the pressure that Israel exerted on the PA leadership after Oslo. The PA was accused by Israel of having failed to crack down on "terrorists." Acts of hostility or terrorism against Israel, including acts whose paternity was claimed by the increasingly popular Hamas or other Islamist groups, led to retaliation targeting PA forces and offices. At the same time, Fatah was facing a challenge from within its own ranks, intensifying the struggle for power between the Force 17 old guard-the military-trained corps surrounding Arafat, which was aiming to become the backbone of the army of the Palestinian state to come-and the "young lions" who had played an active part in both the first and second Intifada and which largely made up the Tanzim recruitment structures. The latter came to be largely identified with Marwan Barghouti and, as the Second Intifada flared up, with the actions of the Al-Aqsa Martyrs Brigade, which pursued a different agenda, and had different operational schemes (and plausibly procurement lines) than, for example, Jubril Rajoub. ${ }^{6}$

Up to Arafat's death in 2004 and the creation of the National Security Council, all PA security forces were accountable to the Ministry of Interior, which continued to be under the strict control of Fatah. ${ }^{7}$ Aiming at keeping a delicate balance of power and strengthening his own leadership, Arafat created a dozen PA security structures. The PLO leadership was aware of its position sandwiched between Israeli confrontational tactics (that is, the threat "from without") and the challenges posed by Islamist groups and dissatisfied PLO militants (that is, the threat "from within"). The inner circles of Fatah thus chose a strategy aimed to incorporate domestic opposition by spending peace dividends. Interesting evidence of this strategy can be found around 1995, when an attempt was made to co-opt Hamas through a deal that would enable its participation in the PA structure, while allowing its men to possess guns (but not explosives). According to the Egyptian filo-governmental newspaper Al-Ahram Weekly, the deal between Arafat and Hamas leader Ahmed Yasin broke down soon thereafter, before any practical consequence could be registered (Caruso 2002:29). As of 1996 the PA Preventive Security Forces were already making massive arrests of Hamas' militants, fuelling dissatisfaction with the PA.

Although little evidence is available about the opening up of specific supply lines, in the aftermath of the Oslo Agreement weapons became increasingly present in the Palestinian society as a whole, and control-mechanisms over this presence increasingly eroded. The demand augmented in tandem with the influx of weapons, the use of unpopular coercive methods on the part of the PA, and frustration with hostile Israeli policies, which continued to strangle the peace process. Thus, only a spark was needed for security structures, opposing factions, clans, and families to explode in multi-dyad armed conflict.

\footnotetext{
${ }^{5}$ Yehia Ayyash was the engineer behind Hamas' ability to utilize explosives as a part of their military strategy. He was providing Raed Zakarneh, Hamas' first suicide bomber, with the required explosives on April 6, 1994, when Zakarneh detonated a bomb by a bus stop at Afula in which eight Israelis were killed and 44 wounded (Chehab 2007:54-56).

${ }^{6}$ Both Rajoub and Barghouti were arrested during the Operation Defensive Shield of April 2002, which systematically devastated all PA government structures in the West Bank (Strazzari 2002).

${ }^{7} \mathrm{Up}$ until 2002, when international pressures to introduce more transparency became stronger, the minister was a PLO-returnee (Challand 2007:66).
} 


\section{The Second Intifada}

The second Intifada, which was sparked by the famous "al-Aqsa promenade" by Ariel Sharon, took a rather different turn than the first popular outbreak, and it can be labeled as a rebellion against both Israel and the Oslo status quo upon which the Fatah leadership was sitting. Two aspects are worth highlighting:

First, the "al-Aqsa Intifada" was far more military in nature. Whilst the first Intifada can be characterized as a popular uprising based on demonstrations and protest, the second Intifada was an armed rebellion. Small arms were employed in the confrontations with the IDF, suicide bombings made victims in Israeli cities, and, from 2001 onwards, domestically produced rockets were fired from the Gaza Strip onto Jewish settlements. A significant rise in arms smuggled into Gaza took place in the years prior to the outbreak of the second Intifada in late 2000, opening channels that were to be consolidated during the rebellion. Boutwell noted in 2002 that the weapons used before 2000 appeared to be primarily "those weapons permitted by the Oslo accords: Kalashnikov and M-16 assault rifles, pistols, and a few jeep-mounted .50 caliber machine guns" (Boutwell 2002:294). However, there is evidence of the use of far more militaristic weapons on the part of the PA security forces and multiple armed groups in the following years. Thus, various Palestinian actors deployed weapons such as Katyusha rockets, mortars, anti-tank land mines, and Qassam-2 surface-to-surface rockets (Boutwell 2002:295).

An illustration of the magnitude of weapons targeting the Gaza Strip in these years can be found in the Karine A incident in January 2002. In this case the Israeli navy intercepted a freighter in the Red Sea, suspecting that the cargo was on its way to the Gaza Strip. The load consisted of a vast range of small arms and light weapons, namely 211 anti-tank mines, 735 hand grenades, and sixty-two 122-mm Katyusha rockets (Bennet 2002). Further, it was reported, the Karine A transported AK-47 Kalashnikovs and 3,000 pounds of C-4 explosives, as well as shorter range 81-mm rockets, mortars, SAGGER and RPG 18 anti-tank missiles, and VR7 anti-tank warheads (Satloff 2002). The Karine A episode patently indicates the existence of a demand for such weapons, whilst it is probable that other similar shipments successfully reached the Palestinian shores.

Another smuggling operation by sea intercepted by the Israeli navy involved a Lebanese fishing boat destined for the Gaza Strip in 2001 (Rudge 2001): The San Torino had departed Tripoli in northern Lebanon with an arsenal of weapons, including Katyusha rockets and Strella anti-aircraft missiles, wrapped in waterproof material and packed into barrels which supposedly were to be dropped out at a designated point off the Gaza coast. Reportedly, the operation displayed a high degree of professionalism and experience in handling arms shipments. Reports indicated that the weapons "were acquired by Ahmed Jibril's Popular Front for the Liberation of Palestine-General Command" (ibid.). To get a rough idea, the US-based New Initiative for Middle East Peace (NIMEP) published a report in 2004 that estimated the number of small weapons available in the Palestinian Territories at more than 70,000, excluding a number of heavy machine guns (Markowitz-Shulman 2004:29).

Over the course of the Intifada arms importation continued to take place in parallel with dynamics of increased polarization within the Palestinian society. This pattern is reflected in several episodes that reveal ongoing smuggling operations, of which the ones mentioned above are indicative. The PA was not able to enforce its monopoly on the use of force, and Gaza witnessed a major influx of arms, especially during the first phases of the uprising. The growing perception of insecurity in Gaza went hand in hand with the erosion of the control mechanisms of the PA, and the rise of Hamas. As a result of this situation, individuals, families, and clans (re)emerged as security-providing actors; in a 
region of traditional "gun-culture" households acquired weapons both for reasons of protection and as a part of the struggle for resistance. In a 2002 Workshop report entitled Traditional Cultural Practices and Small Arms in the Middle East it was concluded that "weapons possession is highly related to resistance and defence [in Palestine] and is therefore legitimized socially" (AFSC and RHSC 2002). The Al-Mezan Center for Human Rights conducted a study on Small Arms and Community Security Perceptions in various Palestinian populated areas in 2005, in which focus group research pointed to the role that the Palestinian Authority had played in emphasizing and strengthening the tribal structures in society. Citizens of Gaza, in particular, expressed their superceding loyalty to families and tribes ahead of the PA institutions and the political parties. Further, the participants in the study identified the PA's inability to separate authorities (security apparatus most notably) and institutionalize them, as well the PA's failure to restrict the use of weapons and to enforce the rule of law as factors contributing to the exacerbation of insecurity (Al-Mezan Center for Human Rights 2005).

The second point of key relevance is that the Palestinian movement was politically more fractioned at the outbreak of the second Intifada. The neopatrimonial system of governance created by the small circle of men close to Arafat came under heavy criticism from all fronts: the revolt was announced as also being against the Palestinians' own leadership, so as to revive the question of a national popular struggle against Israel. The period between the outbreak of the second Intifada and the Hamas takeover of Gaza saw the formation of groups like Al-Aqsa Martyr's Brigades, the Popular Resistance Committees, and the Army of Islam. Importantly, however, is to note that several groups that had been established prior to the al-Aqsa Intifada were now invigorated by the increased arms availability: Al-Qassam Brigades as well as the Fatah Tanzim are examples of such groups. ${ }^{8}$ However, while the purpose here is not to provide an exhaustive list of the various groups that have been active in Palestine or among Palestinian refugee communities in this period, it seems adequate to conclude that fragmentation took place during the second Intifada, and affected not only Gaza and the West Bank, but also refugee communities. ${ }^{9}$ The existence of a plethora of semi-autonomous armed factions within an insurgency renders ceasefires and peace process negotiations extremely difficult, since it multiplies potential peace spoilers, providing their violent actions with a de facto veto power vis-àvis preconditions such as the respect of cease-fire agreements.

The methods adopted by the PA-administered law enforcement agencies are critical to understanding the incentives that exist behind other actors' arms acquisition practices. Especially in the dire living conditions of Gaza, the PA was widely criticized for having made little progress since Oslo, a process that Israel also was respecting only selectively. The PA force was accused of having become Israel's prison guard in the Territories, and of the punishment of patriotic militants whose abnegation was standing out in the face of the corruption of the PA leadership, fed by international assistance. The frequent use of torture and the elimination of persons associated with the Islamist organizations generated fierce antagonism against the government. The Fatah strongman in Gaza, Mohammad Dahlan, was the subject of hate-sentiments fomented by the Islamist groups due to his brutal dealings with opposing parties (Rose 2008).

\footnotetext{
${ }^{8}$ A non-exhaustive list of active groups can be found in The Military Balance (2008:469-470) London, Routledge.

${ }^{9} \mathrm{~A}$ case in point is Lebanon, where the group Fatah al-Islam was established in 2006, plausibly with Syrian support. In June 2007 Fatah al-Islam reached the headlines for fighting Lebanese forces in the Palestinian refugee camp of Nahr el-Bared in northern Lebanon (Scott 2007).
} 
The history of the Palestinian Authority is saturated with over-employment, opaque accountability lines, factional interests, and political expediency. ${ }^{10}$ While many shadows could be cast on the accountability of PA forces, what is relevant here is to highlight that over time it seems that it became increasingly difficult to discern, even among PA officers, which arms could be said to be legal and which, in contrast, were obtained illegally. The relationship between legal and legitimate is however blurry in the Palestinian context; weapons are considered legitimate and therefore "morally legal" when they are directed at the resistance, while viewed as illegitimate when used in internal clashes between families, clans, or groups (Al-Mezan Center for Human Rights 2005). Besides exceeding the permitted amount of arms, prohibited types of weapons such as "light anti-armor weapons, rocket-propelled grenades, anti-tank missiles, light mortars, land mines, and hand grenades" were assumed to have been procured by the security apparatus in the early phase of the Intifada (Luft 2000). While Israeli sources are dubious, the Institute for National Security Studies in Tel Aviv compiled in 2007 an estimated overview of the PA's capabilities, stating that by the 2000s artillery equipments such as mortars and multiple rocket launchers (MRLs), anti-tank missiles of various brands, and surface-to-air missiles were either indigenously produced or acquired through other sources (Institute for National Security Studies 2007). The compilation also shows what we know from journalistic sources, that the increasingly fragmented PA forces were receiving military equipment and training from international sponsors, notably the US, over the course of the second Intifada, and thereby further militarizing society.

\section{Gaza after Israeli Withdrawal 2005}

The 2005 Israeli military and civilian disengagement from the Gaza Strip took place at a time when arms were abundant, a plethora of militant factions were active, support for the Islamist movements was high, and, since the death of Yasser Arafat, the weakness of the Palestinian Authority proved manifest. The withdrawal of both military installations and Jewish settlers was planned and enacted under the Likud-led government and personified by its leader Ariel Sharon. It stirred critiques on both sides of the new border: by (some) Israelis because the move was seen as traitorous and concessive, and by Palestinians because this unilateral move completely omitted them from ownership over the (peace) processes.

Hamas' sweeping victory in the 2006 general elections brought the antagonism that had long existed in the streets into the highest institutional level of government. The power-sharing agreement on the political level could not prevent Hamas' and Fatah's armed wings from battling out their internal disagreements in violent confrontations. Against the political tide of Hamas, and under the pressure of its militant factions, the weak PA police and security forces were not able to prove any institutional autonomy or to hold their ranks; on the contrary, they were fully drawn into the struggle for territorial control and power. At the political level Fatah and Mahmoud Abbas still maintained control over the presidency, but on the ground in Gaza an "uneasy cohabitation" of political and military forces led to increasingly diminishing Fatah influence.

Distinguishing who belonged to the Palestinian police and security forces further complicated the situation. For example, as Hamas entered the Cabinet,

\footnotetext{
${ }^{10}$ For a thorough review of the Palestinian police and security forces see for example Brynjar Lia (2006a) "Building Arafat's Police: The Politics of International Police Assistance in the Palestinian Territories After the Oslo Agreement," and "A Police Force Without a State: A History of the Palestinian Security Forces in the West Bank and Gaza”' Brynjar Lia (2006b).
} 
its militants were integrated into the security forces, allegedly to make armed groups work with the government, and no longer against it (BBC News 2006). This move took place in a situation in which the growing confusions of command lines and the lack of clear structures of loyalty and accountability had already severely curtailed the effectiveness of this force. A tendency within the security apparatus towards warlord-like structures, in which personal charisma determines loyalty, fostered internal strife, rumors of defection, and treason. Working in a security agency came to be equated with membership of a political faction. Superimposed on this, territorial logics and loyalty to clans or extended families became evident. The action of political parties' armed wings such as the Al-Qassam brigades or the Al-Aqsa Martyr's Brigades, often far better armed than the PA officers, further deteriorated the situation. Formal law enforcement agencies were completely incapable of conducting the ordinary tasks attributed to them, adding to the confusion and lack of control.

As a consequence of this deterioration of security standards, a result also of the divisions and corruption existing among PA officers, growing responsibility came to rest on family and clan structures. This was certainly the case in Gaza, where entire clans came to be identified with political factions, but also in troubled areas of the West Bank, such as, for example, the Balata refugee camp near Nablus (Drevon 2006:5). Inadequate law enforcement in combination with a renewed emphasis on gun-ownership and patriarchal clan practices led to a "weaponized" situation: for families and clans primarily concerned with self-defence, small arms such as assault rifles and handguns became the weapons of choice.

The International Crisis Groups reported in spring of 2007 that:

\begin{abstract}
The collapse of law and order has meant both increased militarization and a growing role for families, clans and armed factions as alternative sources of authority particularly in Gaza, but also in the West Bank. (...) According to a former PA minister, families in Gaza "have effectively turned themselves into their own militias." It is often difficult to tell whether factions use families or the reverse. "In the past, families used the political factions as umbrellas for their activities. Now families are becoming the driving force behind some of the factions." "Guns are everywhere, nearly every family has them for protection. The problem is that once you have them, you use them" (International Crisis Group 2007)
\end{abstract}

One of the most well-known clans is the Dughmush clan, located in the northern part of the Gaza Strip and with an estimated extended family counting 15,000 Palestinians, including hundreds of well-armed fighters. The clans offer their services to political factions in a market-driven manner, have gained a reputation of high-profile kidnapping of foreigners, and have arguably become Gaza's new ruling strata (Blanche 2007). Due to the precarious security situation leading up to the 2007 clashes between Hamas and Fatah, the clans served as a security provider for ordinary Gazans that sought protection from the violence. The aftermath has proved that several clans, including Dughmush, have gained a solid foothold in Palestinian internal affairs (Al Jazeera 2007).

Making a reliable estimate of the number of weapons brought into Gaza since the 2005 disengagement is difficult. According to an Israeli intelligence report dated August 2006, " 15 tons of TNT, four million bullets, 15,000 guns, 2,300 pistols, 65 RPG launchers, dozens of anti-tank missiles, 400 RPGs and between 10 and 15 Katyushas" had entered the Strip since the IDF withdrew (Drevon 2006:6). While these figures mean little per se, they nonetheless indicate the existence of a trend of arms supply and demand.

The most visible consequence of the Israeli disengagement was the increased capability of militia groups to develop and launch homemade rockets from the 
Gaza Strip into Israeli cities. The manufacture of rockets was not a new phenomenon on the part of Palestinian armed factions, but unprecedented was the control of territory, a crucial factor for launching them. The technical improvements in their manufacture were also new, and considerably enhanced the potential for inflicting severe damage on Israeli soil. One can try to compile a brief overview of the domestic production of rockets by mainly relying on information provided by an organization called Weapons Survey which, again, chiefly derives its data from the most comprehensive, yet obviously biased, source that is available: Israeli intelligence.

The most well-known and successfully manufactured rockets are the Qassams $(1 / 2 / 3 / 4)$, as mentioned above. These simple short-range rockets are produced from sugar and potassium nitrate (saltpeter), and are famous for their inaccuracy. The Qassam rockets (2007) are mainly produced and operated in the Hamas stronghold of Gaza, although the IDF claims to have found Qassams in the West Bank as well. Hamas has also manufactured Nasser-3 rockets, apparently an improved version of the Qassam 2, and it has allegedly been able to manufacture an indigenous variant of the Russian-origin Katyusha rocket, which has a 24-km range. The possession of Katyushas is a highly contested issue, and the speculations of whether Palestinians are supplied with these rockets by Iran or Hezbollah remains a matter for classified documents.

In addition, Islamic Jihad has since April 2006 been capable of producing Quds-rockets, also knows as Katyushas, as well as Saria-2 rockets. Al-Aqsa Martyr's Brigades allegedly produced the Kafah-rocket as early as 2004, and in 2006 they announced the production of Aqsa-rocket with a $17-\mathrm{km}$ range. Further, in January 2006 it was reported that the Jenin-1 rocket was developed in the West Bank. The Yasser Arafat (1/2) rockets were launched against Israeli targets from 2004. Jenin Martyr's Brigade has successfully manufactured the 55-km range Hawkeye rockets. Al-Bana, Al-Yassin, and Al-Batar anti-tank missiles have, furthermore, been produced in the Palestinian territories (Weapons Survey 2007).

A study on arms dynamic and violent insurgency has to note how critical the ability to produce rockets is for the insurgency's unity and coherence; the widespread availability and control of weapons with a strike capacity of this magnitude not only affects any leadership's intentions of engaging in peace talks due to the "veto-power" of a rocket-launch, but it also makes it much easier for any small group of militants to claim their position in the archipelago of insurgent armed actors, without having to engage in direct confrontation. When rockets capable of being fired into Israeli territory can be manufactured in any person's garage, there are significantly fewer disincentives to actively participate in the insurgency, on one's own terms.

Boutwell (1999) points out that the primary motivation for acquiring weapons in the Palestinian territories is political, rather than economic. However, transnational networks operating in the Territories and in adjacent countries are reported to be part of the smuggling of weapons, regardless of whether the supply side is politically connoted or simply acting along profit lines as a segment of the wider regional black market. Bedouins who live in Gaza, particularly in the area near the Rafah border crossing, are reportedly engaging in weapon smuggling activities. Increasingly marginalized and discriminated against, Gaza's Bedouins have been compelled to resort to smuggling to ensure sheer survival and a minimal standard-of-living. Interviewed by a journalist, a local Bedouin asserted that "smuggling has long been a part of the Bedouin life, but weapons smuggling to Gaza began in earnest with the start of the first Palestinian Intifada 20 years ago" (Slackman 2007).

These preliminary observations indicate that the illicit influx of arms following the PA inception in 1993 generated a shift in the Palestinian movement. Several actors-and above all, those actors who were dissatisfied with the direction that 
the PA was giving to the historic struggle of the Palestinians for the right to selfdetermination-began to independently acquire arms, while mechanisms of accountability for the weapons that were legally in circulation were increasingly eroded. Soaring demand is likely to have caused a rise in prices, which rendered smuggling more lucrative, thus feeding the supply; as a result, more weapons were available. The relatively high level of arms accessibility, in turn, made the number of militias and aspiring armed groups multiply, further relinquishing the PA mechanisms in control of the acquisition, whose forces ended up trapped in a situation of domestic splintering, leading to a series of violent incidents that witnessed the intensification of intra-Palestinian conflict, all the way down to the Gaza battle of June 2007.

\section{Conclusion: On Weapons and New Agendas}

We have argued in this article that the process whereby the Palestinian armed struggle has transformed is deeply interrelated with dynamics of arms availability in the Territories. Born along the trail of national liberation movements, following a model of political control and quasi-monopoly of action against the occupying force, the Palestinian struggle was from its very origin heavily imbued with the discourse of the "nation in arms." Since its foundation Fatah exhibited flags and emblems featuring machine guns and rifles. Yasser Arafat's visit to the UN General Assembly in 1974 is emblematic in this regard: his carrying an (unloaded) weapon left no ambiguity as to the legitimacy of the armed struggle for self-determination. Due to many factors, several of which are described in this paper, weapons availability was low in the Palestinian territories up until the second Intifada. This partly explains why the PLO centered its resistance around strongholds in adjacent Arab countries. Yasser Arafat kept strict control over finances and armaments in his attempt to take the PLO along a statist path towards liberation through a hierarchically structured organization. The PLO appears to have been able to control the national movement and its armed wings well into the 1990s. Although in specific circumstances and episodes some of the militant groups acted independently of the PLO leadership, it is unlikely that groups contravening the PLO politico-military strategy would have been able to sustain their effort, as examples in this article show.

Access to weapons supply lines would necessarily entail turning to external sources, through operations requiring skills and contact networks that only the PLO could have at the time. Although Hamas enjoyed increasing support among the Palestinian diaspora (and was for a long time not actively countered by the Western security apparatus), ${ }^{11}$ its much-debated alignment with other organized Islamist groups occurred later. ${ }^{12}$ The establishment of the Palestinian Authority in 1994 was the start of a phase in which one can observe the rise of arms in the Territories. The first Intifada had reactivated a latent understanding of violent mass rebellion as a prerequisite to ending the occupation, which

\footnotetext{
${ }^{11}$ For the purpose of illustration; in 1990 Hamas held its general congress in Texas, USA (Caruso 2002).

${ }^{12}$ Key to this development was the looming of a "state-inside-the-state" model, partly derived from the Lebanese scenario. This model grew next to the "national liberation movement" model. Up to the early twentyfirst century the linking of Lebanon to Palestinian militants meant evoking the defeat of 1982, or referring to the Syrian-backed bases of armed groups of the secular left. The withdrawal of Israel from Hezbollah-held Southern Lebanon galvanized all those who intended to show that it is possible to force the Israeli enemy out through the determination of a properly conceived armed strategy: a precondition for reaching the determination that this effort required was to get rid of the corrupted Palestinian leadership, whose daily deals with the Israeli enemy were portrayed as stabbing the national cause in the back. For its part, Hezbollah blew on the fire by not sparing virulent verbal attacks against the PA leaders, and by making explicit that it saw in Hamas the actor that can make of the Gaza Strip a second Southern Lebanon.
} 
resulted in an increase of the demand for weapons by a growing number of segments of society. At first weapons were not within reach in the Occupied Territories, and the direction of the movement was intent on capitalizing on low levels of widespread violence, and constraining the use of weapons. Over time the failure to reach a political settlement with Israel, the economic suffocation under the PA's mandate, the ensuing deterioration of living standards, and the growing popularity of Hamas, resulted in a precarious security situation where the demand and supply of weapons increased. The second Intifada was thus more violent and more fractioned in nature: numerous fighting factions, often uncoordinated or loosely coordinated, attacked Israel. Although tactical coordination was attempted, it is difficult if not impossible to discern through the fog of war either a unified leadership, or a single strategy.

In analyzing how weapons availability changed over time and space in this context, it is necessary to take into account how the strategic landscape, and the opportunity structure of acquiring weapons, was fundamentally molded by the occupation forces. In the case of Israel, this has meant not only undertaking specific counteraction, but also embarking upon a major engineering effort to alter the morphology of the Territories and their human geography: over the period to which this observation refers, acts of land expropriation, settlement policies, water exploitation and the building of walls and exclusive roads and communication lines cutting across the landscape, as well as evolving tactical and strategic disposition, have deeply reshaped the maps of the Palestinian question. The changing territorial configuration, and the unpredictable evolution of mobility, has had severe effects on the organization of the Palestinian society at large; politico-military command lines and commodity supply are no exception. One can plausibly argue that the result has been a situation of fragmentation that is reflected also in terms of arms procurement; small units need to seek their own way towards self-maintenance, and where self-reliance on the fringes is rewarded, the centrifugal consequences are predictable.

The fact that Israel had negotiated at Oslo new territorial arrangements that led to its departure from the cities in the Occupied Territories was portrayed not as the sign of a genuine commitment to the respect of the terms of the peace plan, but as the result of the growing human and political costs that the Jewish state ended up paying for its occupation, and the prospective burden of these costs; the Palestinians were growing demographically, Israel appeared to be increasingly sensitive to its own victims, and armed incidents were multiplying. All it would take, to reach success, was more determination in pursuing the "Lebanese model," which included the magnification of the image of the martyr, and even the suicide bomber. In this context, growing arms availability fed a mechanism that further eroded the consolidated methods of political control that existed under the "liberation movement model" leading up to the Oslo Agreement. In contrast, as weapons are smuggled in or trickled down, one can witness the shaping of a mosaic where loosely coordinated or uncoordinated militias would soon make the terrain extremely costly for fighting; a hell where any attempt to engineer a "peace process" becomes impossible. At the same time, high availability of arms in conjunction with the evaporation of rule of law gave incentive and space for intra-Palestinian grievances to be expressed by violent means.

The link between accessibility of weapons and the detonation of intra-Palestinian fighting can in no way be described in terms of linear mono-causality. A comparative research design clarifying how a complex set of factors have interacted with weapons availability are well beyond the scope of this reconstruction. What emerges here are preliminary conclusions on how the access to weapons has contributed to the internal fragmentation within the PA mandated areas. One can hardly understand the nature of the events that occurred between the first Intifada and 
the June 2007 battle of Gaza without taking into serious consideration the correspondence that exists between arms availability and political choices. From this observation Marsh's hypothesis seems to be corroborated by further evidence; the mode of insurgency is closely related to the factor of arms availability. Also, keeping in mind the biased, unstable, and partial nature of the information available to the researchers working in this field, the "weapons factor" has arguably been key to the shift occurring from a united liberation movement to a system that is fractured along political and military lines. Small arms and light weapons have been in large part the protagonists of this process. Shedding light on the mechanisms that make these weapons available generates understanding of how contemporary conflicts are amendable according to exogenous factors that interact with endogenous decision making.

\section{References}

Al JazeEra. (2007) Release: Sheikh Saleh Dughmush. July 4. Available at http://english.aljazeera. net/Services/Templates /FreeTemplate.aspx?Rq=6) O7AGuNR-5HhKZr=HU-6qZ2ZLoaL5HCDBMwBb-6a(b9YwKy-6X!4CrYIq-5Is2ZSHya-6GDqXfb9g-.f. (Accessed November 28, 2008.)

Al Mezan Centre for Human Rights. (2005) Field Study: Small Arms and Community Security Perceptions in Northern Gaza and Ramallah. Gaza City: Palestinian Territories.

American Friends Service Committee (afsc) and the Regional Human Security Centre at The Jordan Institute of Diplomacy (RHSC). (2002) Workshop Report: Traditional Cultural Practices and Small Arms in the Middle East: Problems and Solutions. Workshop, November 3-4, 2002, Amman, Jordan.

Atwood, David, Anne-Kathrin Glatz, and Robert Muggah. (2006) Demanding Attention: Addressing the Dynamics of Small Arms Demand. Geneva: Small Arms Survey.

BBC News. (2006) Hamas Reveals New Security Force. April 20. Available at http://news.bbc.co.uk/ 2/hi/middle_east/4928152.stm. (Accessed November 29, 2008.)

Bennet, James (2002) Sharon, Showing Seized Arms, Calls Arafat. New York Times, January 7. Available at http://query.nytimes.com/gst/fullpage.html?res=9801E1DA1739F934A35752C0A9649C8B63. (Accessed November 28, 2008.)

Blanche, Ed. (2007) Gaza's War of the Clans. The Middle East, July 1. Available at http://findarticles. com/p/articles/mi_m2742/is_380/ai_n25009204/pg_1. (Accessed November 29, 2008.)

Bourne, Mike. (2007) Arming Conflict: The Proliferation of Small Arms. Hampshire: Palgrave Macmillan.

Boutwell, Jefrrey. (1998) A Gusher of Illegal Weapons. Los Angeles Times, August 18. Available at http://articles.latimes.com/1998/aug/16/opinion/op-13644. (Accessed June 20, 2007.)

Boutwell, Jeffrey. (1999) The Wild West Bank. The Bulletin of the Atomic Scientists. January/ February.

Boutwell, Jeffrey. (2002) Weaponization of the Israeli-Palestinian Peace Process. The Brown Journal of World Affairs IX: 293-304.

Caruso, Antonella. (2002) La Palestina di Hamas sorgera' sulle ceneri di Israele. Limes 2: 37-43.

Challand, Benoit. (2007) Palestinesi contro. Una storia lunga quarant'anni. Limes 5: 57-77.

Challand, Benoit. (2008) Les mutations du leadership Palestinien. A Contrario 5: 52-75.

Challand, Benoit. (2009) Fatah-Hamas Rivalries After Gaza: Is Unity Possible? The International Spectator: Italian Journal of International Affairs, 44 (3): 11-17.

Сненав, Zaкi. (2007) Inside Hamas: The Untold Story of Militants, Martyrs and Spies. London: I.B. Tauris \& Co. Ltd.

Creveld, Martin van. (1997) What is Wrong with Clausewitz? In The Clausewitzian Dictum and the Future of Western Military Strategy, edited by Gert de Nooy. The Hague: Kluwer Law International.

Drevon, Jerome. (2006) Small Arms, Light Weapons and Insecurity in Palestine. Gaza City: Palestinian Human Rights Monitoring Group.

Duffield, Mike. (1998) Postmodern Conflict: Warlords, Post-adjustment State and Private Protection. Civil Wars 1: 65-102.

DuQuet, Nils. (2008) Arms Acquisition Patterns and the Dynamics of Armed Conflict: Lessons from the Niger Delta. Brussels: Flemish Peace Institute, unpublished working note.

Eavis, Paul. (2002) SALW in the Horn of Africa and the Great Lakes Region: Challenges and Ways Forward. The Brown Journal of World Affairs IX: 251-260. 
Garcia, Denise. (2006) Small Arms and Security: New Emerging International Norms. Oxon, UK: Routledge.

Global Security. (2007) Qassam Rockets. Available at http://www.globalsecurity.org/military/ world/para/hamas-qassam.htm. (Accessed June 20, 2007.)

Institute for National Security Studies. (2007) Palestinian Authority. Available at http:// www.inss.org.il/upload/(FILE)1188812953.pdf. (Accessed June 20, 2007.)

International Crisis Groups. (2007) After Mecca: Engaging Hamas. Middle East Report No 62.

Kaldor, Mary. (1999) New and Old Wars: Organized Violence in a Global Era. Cambridge, UK: Polity Press.

Kaldor, Mary. (2005) Elaborating the 'New War' Thesis. In Rethinking the Nature of War, edited by Isabelle Duyvesteyn and Jan Angstrom. London: Frank Cass.

Klare, Michael T., and David Andersen. (1996) A Scourge of Guns: The Diffusion of Small Arms and Light Weapons in Latin America. Washington, DC: Federation of American Scientists.

Kuzmar, Khaled. (2002). The Phenomenon of Small Arms and Light Weapons in Palestine. Paper presented at the Regional Workshop on Small Arms and Light Weapons in the Arab Region: National and Regional Measures. Amman, Jordan: Regional Human Security Centre at the Jordan Institute of Diplomacy, May 6-7 2001.

Legrain, Jean-Francois. (1997) Hamas: Legitimate Heir of Palestinian Nationalism? In Political Islam. Revolution, Radicalism or Reform? edited by John L. Esposito. Boulder-London: Lynne Rienner.

Lia, Brynjar. (2006a) Building Arafat's Police: The Politics of International Police Assistance in the Palestinian Territories After the Oslo Agreement. New York: Ithaca Press.

Lia, Brynjar. (2006b) A Police Force Without a State: A History of the Palestinian security Forces in the West Bank and Gaza. New York: Ithaca Press.

Luft, Gal. (2000) Palestinian Military Performance and the 2000 Intifada. Middle East Review of International Affairs 4: 4.

Markowitz-Shulman, Aaron A. (2004) Disarming Palestinian Militant Groups: A Civil Society Approach in New Initiative for Middle East Peace bulletin. NIMEP Insights 1: 25-40.

Marsh, Nicholas. (2007) Conflict Specific Capital: The Role of Weapons Acquisition in Civil War. International Studies Perspectives 7: 54-72.

Morris, Benny. (1999) Righteous Victims: A History of the Zionist-Arab Conflict, 1881-1999. New York: Vintage Books.

Nasser, Jamal R., And Roger Heacock. (1991) Intifada: Palestine at the Crossroads. New York: Praeger Publishers.

Odell, J.S. (2001) Case Study Methods in International Political Economy. International Study Perspectives 2: 161-176.

Rose, David. (2008) The Gaza Bombshell. Vanity Fair. Available at http://www.vanityfair.com/ politics/features/2008/04/gaza200804. (Accessed December 15, 2007.)

Rudge, David. (2001) Navy Captures Boat Full of Weapons Bound For Gaza. Jerusalem Post, May 8.

Sale, Richard. (2002) Hamas History Tied to Israel. United Press International.

Satloff, Robert. (2002) The Peace Process at Sea: The Karine-A Affair and the War on Terrorism. Washington: The Washington Institute for Near East Policy.

SAYigh, Yezid. (1997) Armed Struggle and the Search for State: The Palestinian National Movement 19491993. Oxford: Clarendon Press.

Schiff, Ze'Ev, AND Ehud YA'ARI. (1989) Intifada: The Inside Story of the Palestinian Uprising that Changed the Middle East Equation. New York: Touchstone.

Sislin, John, and Frederic S. Pearson. (2001) Arms and Ethnic Conflict. Lanham: Rowman \& Littlefield.

Slackman, Michael. (2007) Running Guns to Gaza: A Living in the Desert. New York Times, June 19. Available at http://www.nytimes.com/2007/06/19/world $/$ middleeast $/ 19 \mathrm{rafah} . \mathrm{html}$ ?ex= $1339905600 \&$ en $=743787779930$ b750\&ei $=5090 \&$ partner $=$ rssuserland\&emc $=$ rss. $\quad$ (Accessed June 22, 2007.)

Strazzari, Francesco. (2002) La battaglia di Ramallah. In Limes 2.

Tamini, Azzam. (2007) Hamas: Unwritten Chapters. London: C. Hurst and Co. Publishers Ltd.

Weapons Survey. (2007) Missiles and Mortars. Available at http://www.weaponsurvey.com/missilesrockets.htm. (Accessed May 15, 2007.)

Wilson, Scott. (2007) Splinter Groups Rise in Refugee Camps: Decline of Palestinian Institutions. Washington Post, May 22, A10. 